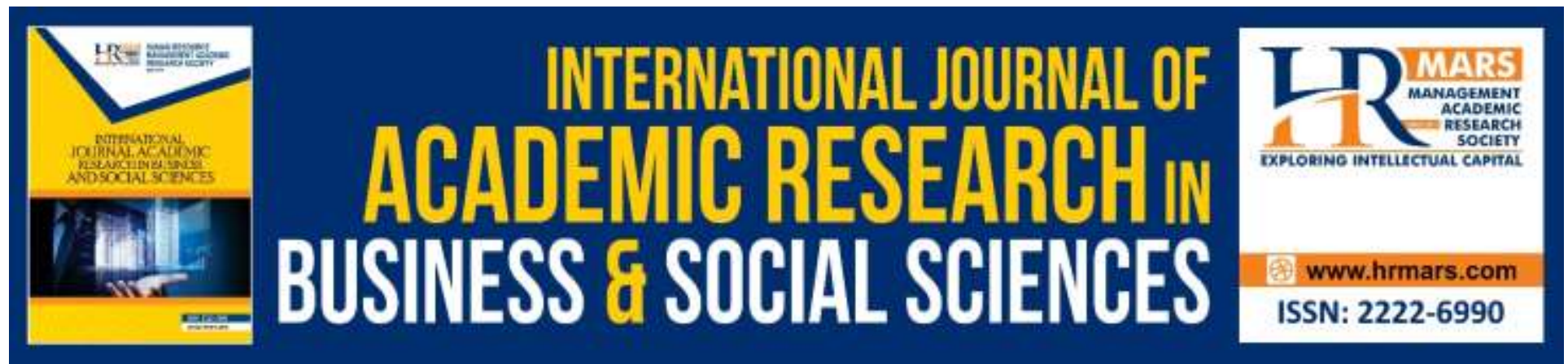

\title{
Perceived Incongruity of Gender and Leadership Roles: Experiences of Top Women Leaders in Malaysian Sports Associations
}

\author{
Mirian P. Aman, Aminuddin Yusof, Abu Bakar Razali \& Roxana Dev Omar \\ Dev
}

To Link this Article: http://dx.doi.org/10.6007/IJARBSS/v9-i11/6709

DOI: 10.6007/IJARBSS/v9-i11/6709

Received: 01 October 2019, Revised: 24 October 2019, Accepted: 05 November 2019

Published Online: 29 November 2019

In-Text Citation: (Aman, Yusof, Razali, \& Dev, 2019)

To Cite this Article: Aman, M. P., Yusof, A., Razali, A. B., \& Dev, R. D. O. (2019). Perceived Incongruity of Gender and Leadership Roles: Experiences of Top Women Leaders in Malaysian Sports Associations. International Journal of Academic Research in Business and Social Sciences, 9(11), 1429-1433.

Copyright: (C) 2019 The Author(s)

Published by Human Resource Management Academic Research Society (www.hrmars.com)

This article is published under the Creative Commons Attribution (CC BY 4.0) license. Anyone may reproduce, distribute, translate and create derivative works of this article (for both commercial and non-commercial purposes), subject to full attribution to the original publication and authors. The full terms of this license may be seen at: http://creativecommons.org/licences/by/4.0/legalcode

Vol. 9, No. 11, 2019, Pg. 1429 - 1433

Full Terms \& Conditions of access and use can be found at http://hrmars.com/index.php/pages/detail/publication-ethics 


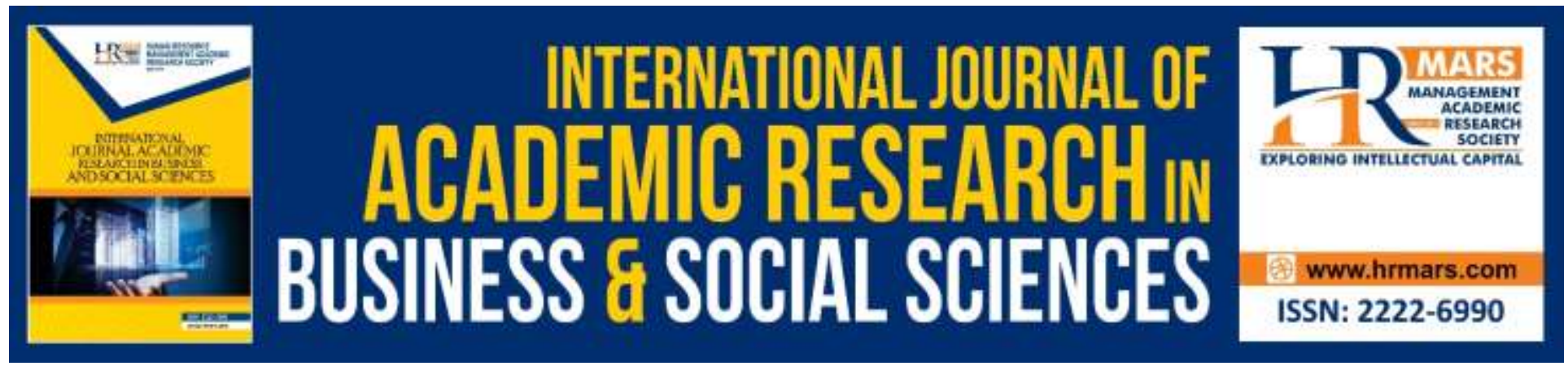

\title{
Perceived Incongruity of Gender and Leadership Roles: Experiences of Top Women Leaders in Malaysian Sports Associations
}

\author{
Mirian P. Aman ${ }^{1}$, Aminuddin Yusof $^{2}$, Abu Bakar Razali² \& Roxana \\ Dev Omar Dev² \\ ${ }^{1}$ College of Sports, Physical Education and Recreation, Mindanao State University, 9700 Marawi \\ City, Philippines, ${ }^{2}$ Faculty of Educational Studies, Universiti Putra Malaysia, 43000 UPM
}

Serdang, MALAYSIA

\section{Abstract}

This study investigates the experiences of top women leaders in Malaysian sports associations with regard to discrepancy of gender and leadership roles, organizational discrimination, and pipeline problem in sport organizations. Data were collected through in-depth, face to face semi structured interviews, observations and document analysis involving seven women leaders in national sport organizations. The theme that emerged from the data was "experiences" related to the discrepancy of gender and leadership roles, organizational discrimination and leadership pipeline problem. These experiences result in the bias judgment against women as leaders, being denied of access, less supported and women being denied access to leadership positions. The results were discussed using the role congruity theory, homologous reproduction and pipeline problem. The findings in this study concluded the prejudices within the sporting system of the country contribute to the diminishing number of women role models because they opt to get out from the system than to embroil themselves into the situation. Consequently, there is a higher possibility for a fewer aspiring women leaders to pursue for leadership position.

Keywords: Sport Leadership, Leadership Roles, Pipeline Theory

\section{Introduction}

Leadership can be described as the ability of an individual to influence, and enable subordinates to achieve the goals of an organization (House, Hanges, Javidan, Dorfman, and Gupta, 2004; Saybani, Yusof, Soon, Hassan, \& Zardoshtian, 2015). Even though leadership is not a male 
prerogative, the literature suggests leadership has been predominantly dominated by males, not only in sport, but also in other sectors such as business organizations, political parties, and the military (Eagly \& Karau, 2002).

Some authors pointed out that women are less likely than men to be associated with leadership (Latu, Mast, Lammers, \& Bombari, 2013), and women face more challenges than men which reduces their ability to become leaders. In sport leadership predominantly dominated by men, female leaders would likely to receive a negative evaluation to possess leadership roles for such premise of violating women's social characteristic standards. This negative evaluation thus prevents women from even being categorized as leaders (Scott \& Brown, 2006) specifically in sport organizations.

According to Turkel (2004), few women become top leaders because of a lack of women leaders in the lower level. Mariani (2008) suggests women are underrepresented in male dominated fields such as leadership because few women are prepared to enter those fields. Other reasons for the lack of women leaders are women's family responsibilities and the tendencies for women to display leadership traits and of level positions (Browne, 1999). Greenhaus \& Parasuraman (1999) proposed the idea of a "pipeline problem" to explain for the lack of qualified women leaders.

Coaching and leadership at the lower administrative level, are the career path to top leadership positions in sport, but because of there are few women at the lower level makes it difficult to move into top leadership positions (Massengale, 2009). Even though there are more women as athletes and officials which can be a source of leadership pool, but the underrepresentation of women is still prevalent in the higher level of management.

This phenomenon of the underrepresentation of women in top leadership positions in sport is an issue that attracts the attention of every sport woman advocate to break the barriers so that women can have better opportunities and realize their full potentials. The issue of women underrepresentation in sport leadership is currently one of the main issues at the forefront of the society (Inglis, Danylchuk, \& Pastore, 2000). Sport management researchers have conducted research produced findings with regard to diversity in leadership on women representation in top leadership positions (Sartore \& Cunningham 2007), but most of these studies were done in the West at different levels of sport leadership positions (e.g., Massengale: 2009, Hancock \& Hums, 2014; Lovelin \& Hanold, 2014; Hederson, Grappendorf, \& Burton, 2011).

In Malaysia, there is a lack of study on the issue of women underrepresentation leadership positions. Most were conducted on managerial positions in the business sectors, (e.g., Osi, llac, \& Amante, 2012; \& Subramaniam \& Arumugam, 2013), economics (Saadin, Ramli, Johari, \& Harin, 2016), as well as politics (Sobritchea, 2000). Although, opportunities for Malaysian to participate in the workforce in the country are increasing from $43.05 \%$ in 2008 to $50.79 \%$ in 2017 (https://www.theglobaleconomy.com/Malaysia/Female_labor_force_participation), and the government has embarked on a policy of 30\% women's equity in managerial and leadership position in the public sector, but very few women held top leadership positions in sport associations (Daud et al., 2013). Thus, there is a need to provide an in-depth understanding on the underrepresentation of women in sport leadership positions of sport organizations in 
Malaysia.

The study seeks to investigate the lived experiences of women leaders purposively selected from the national sport organizations and among the top executive leaders of the organization, who were directly involved in decision making and administration. Specifically, this study investigated women top leaders' experiences related to the prejudices brought about by perceived incongruity of gender and leadership roles, homologous reproduction and pipeline problem and how these perceived sociocultural and organizational barriers impede their ability to ascend in leadership positions.

The current study sought to address the following research question: What experiences do women leaders encounter that are associated with the discrepancy of gender and leadership roles, organizational discrimination, and pipeline problem in sport organizations?

\section{Theoretical Framework}

In this study, the constructivist paradigm was used to understand the perspectives of top women leaders in Malaysian sports organizations in order to create the meaning of their experiences. This approach allowed the research participants to fully and freely describe their own experiences (Creswell, 2013). Based on the role congruity theory (Eagly and Dickman, 2005), a behavior is positively evaluated if it is in alignment with categories constructed by society. Characteristic such as leadership is socially constructed aligned to men's gender roles thus women who exhibit such character are negatively evaluated and perceive to defy woman social gender roles.

The social construct differentiates men from women as opposite gender thus differ in capabilities and performance. When women perform characteristics not socially categorized for them, they were perceived incongruent to their gender roles. According to this perspective, women face hindrances in acquiring leadership position in sport organizations because of the notion in society that such behavior is only suitable for men who have traditionally held roles in the organization. These perspectives act to keep women to lag men and women are less competent for the position of leadership positions.

The traditional and cultural practices of Malaysia provided a greater explanation for this notion since gender roles still upholds in considering leader emergence. These traditional and cultural practices create homologous reproduction (Kanter, 1977) for the dominant males who are in the majority, to reproduce more leaders based on social and/or physical characteristics. This can be seen in Malaysian sport organizations where this systematic reproduction is being accomplished by hiring and promoting men who are in the majority, to top leadership positions in sport. This theory significantly provided a deeper explanation to the existing structural organizations in Malaysia which is apparently dominated by men.

The homologous reproduction perspective provided an explanation as to whether the country's social male dominance model of leadership had an impact on women's underrepresentation of leadership positions in sport. Turkel's (2004) pipeline problem theory explained that few women ever reach to top leadership positions because of a lack of women at the lower level. This is attributed to the limitations among women which include self-limiting behaviors, 
lack of intention to pursue for leadership positions and lack of connection and engagement in the sport system, consequently contributed to the low representation of women even at the lower level of management, making the selection pool limited hence, created a pipeline problem. This in turn led the majority males to produce more leaders because of the perception of a lack of potential leaders among women in the organizational pipeline who aspire to be top leaders.

In this study, the theoretical framework consists of the interplay of the three theoretical perspectives to give meaning to the experiences of the women sport leaders through social constructivist research paradigm to construct their knowledge inductively. The theoretical framework examined the sociocultural, organizational and personal experiences of the women top leader that shape the construct of the reality of the social world where they live and work. Hence, the three theoretical perspectives acted as the rationale of the current study and constructivist set of beliefs provided greater explanation of the underrepresentation of women in sport leadership of sport organizations.

\section{Methods}

In this study, a qualitative phenomenological research design was used to collect data using face-to-face semi-structured interviews, observations and document analysis. A total of seven participants were chosen from among women of top leaders in Malaysian sports association. They were members of the Executive Board, General Secretary, Head of the Department, President, Deputy President, and Vice President of sport organizations in Malaysia, with at least two years' experience in that position. Each participant was interviewed three times with each session lasting about 40 minutes. In addition, the researcher also observed meetings and events in which the participants are involved. Women's Underrepresentation in Sport Leadership Pipeline Problem Homologous Reproduction Role Congruity Culture and Tradition Expectation Perceive Gender and Leadership Roles Self-limiting Behavior Limited Networks Treatment Discrimination Access Discrimination Besides using digital recorder, field notes were also taken to record things which the recorder could not capture such as the emphases placed on certain issues or phrases used, emotions displayed or facial expressions.

A constant comparative analysis, involving a data-analytic process, was employed to have a better grasp of the data. This process involves comparing each interpretation with the existing findings as it emerges from the data analysis until properties of all categories and its relationship between other categories are clear (Parry, 2011). Beginning from organizing data from documents, field notes observations were also analysed as well as transcripts of interviews. This process allows immersion in the data to obtain the sense of it and continues until the initial coding process following Charmaz (2006). In the next step, themes were developed, codes identified and groped to form broader and overarching themes.

\section{Results}

The theme that emerged from the data was "experiences" related to the discrepancy of gender and leadership roles, organizational discrimination and leadership pipeline problem. Whereby, the participants convey their experiences which they personally encountered whether 
they are the primary subject or the women leaders in general, where these experiences lead to the notions of role congruity theory, homologous reproduction and pipeline problem. The consequences of such theories were the bias judgment against women as leaders, being denied of access, less supported and lack of women in the leadership pipeline. The participants have common experiences which were identified as subthemes: gender stereotypes, organizational prejudice and candidate pool problem.

\section{Gender Stereotypes}

Role congruity theory predicts that female leaders experience prejudice because the role of leader aligns more closely with the stereotypic male gender role than it does with the stereotypic female role (Ferguson, 2017). Hence, social construct stereotype resulted to designate women in a leadership position and expected to act and behave according to gender role prescription attributed to them.

The participants in the study affirmed that because of how the society stereotype women's gender and leadership role they were placed in a role secondary to men or in a position for women affairs. Although in the sport organizations of the country there were no written policies that prohibit women not to contest for the highest position in the organization, however, it is stereotypical and customary for women to be placed in a specific position for a particular role. Interviewee 1 is hopeful for a time to come that women will be more daring to run for position atypical to what is accustomed.

"I want women representation not base on the two positions. I would like to have it on the Vice President to be woman there. I would like to have Deputy President of X Council to be woman, not to be dictated in a position for the women. But then the truth is we need to have an organization that accepts women as leaders in the sport organization. Like $X$ Council itself never have any women on the top level, always men. And then they will have a position specifically for women and that women only go for that spot. There's a time women should be carrying themselves well and saying, you know, I can be a president of an association. We should stop representing the women only. We should be strong enough to say that we can represent the men as well. Yes, we can."

Interviewee 2 concurred to this idea identifying qualified women leaders who could be in a position known to be for men rather than just being in one position assigned for women because it is for women.

“...because even look at X Council, all the Vice Presidents are men except for the woman Vice President role. Why aren't there more women? Like Ms. W shouldn't be fighting with Datu $X$ and Dr. $Y$ can also be in that Vice President role. Anna also can be Vice President and Datu $Z$ also can be Vice President...but because men are in power so they get to control where women are placed in a certain situation." 


\section{Organizational Prejudice}

Organizational prejudice is brought about by homologous reproduction. It is a notion developed by Kanter (1977) which emphasized three interacting determinants in the organization's structure such as, power, opportunity, and proportion. To illustrate in an organizational setting, as one gains power, more opportunities of like image personnel are available, thus in return will increase its proportion (Knoppers, 1987).

The consequence of homologous reproduction where the majority is in control over a setting or situation by power, opportunities and proportion they likely to have the capacity to discriminate the minority. The participants in the study experience two forms of prejudice such as "treatment discrimination" and "access discrimination" which they considered restraining factors for women to attain leadership positions in the sport organization. It is apparent that both access and treatment discriminations are present at the organizational level of sport organizations and negatively impacted women in leadership positions (Burton, 2015). Interviewee 3 cited an example of an ex-athlete where she helped to make her way for leadership but because this woman was vocal to speak her mind thus, the organization made it difficult for her.

"But sometimes, the limitation is also the association. Because I know of one ex-athlete who comes back and I make the way for her, put her as this thing and she was doing well with the juniors. But the association is not happy with her because she speaks her mind. So, they made life very difficult for her so, she decided to come-out. I think it's still very much a man's world."

Interviewee 4 as well alluded in her own encounter where she felt discriminated with the treatment men showed to her (and women in general) in her organization.

"But hopefully, men can allow us to be more active and strengthen the policy to get women more involve. Allow us! Definitely we cannot compete with them. But please allow us. Because it affects....still affect. You know, sometimes, they don't listen to us. It's not that easy for us to convince them. They make us so difficult...they don't make us so easy. But if you ask me personally, I take this as a challenge for me. So, I learn more, I learn how to control myself, my emotion, my temper how to put in. To make them until they surrender, they must say yes!"

In addition to the kind of discrimination other participants' experience, Interviewee 7 also noted a kind of discrimination in the discrepancy of rewards given to women. She pointed out:

"When they give any ahh...achievement awards, for example, for leaderships, for sport leaderships they always think of a man, they will give the award to men. Whereas actually we have other kind of sports which is women's hockey...women's football. But they will think the game as the men's game. So, the women's only fill in, just to fill the...it's like a 
quota to them." Interviewee 6 as well agreed to the evident treatment discrimination in the organization by placing in a position or job they (women) do not deserve because of gender issue "but sometimes they are not really putting us in a right place, in the right job, where the genders are problem."

\section{Candidate Pool Problem}

Another experience the participants encountered in the sporting system of the country is related to the pipeline problem. The participants in this study, who represent different organizations experience difficulty to look for potential leaders thus, recognize candidate pool problem. With the limited hiring pool of candidates, it resulted to create problem in the pipeline of leadership.

Pipeline problem (Turkel, 2004) is another hypothetical explanation for the underrepresentation of women particularly in sport leadership.

This idea of a pipeline problem explained that not many women ever reach to the top leadership because there have been not many potential women leaders in the lower level. According to this point of view, the lack of women leaders is due to the absence of women getting ready to enter those fields (Mariani, 2008). It is likewise ascribed to assortment of causes, including family obligations and acquired tendencies for women to show less of the attributes and inspirations that are important to accomplish and make progress in top level leadership positions (Browne, 1999).

Malaysia has been participating in many international sport competitions such as, SEA Games, Asian Games, Commonwealth Games and the Olympic Games. In the history of the country's participation, women athletes' participation as well increased. However, the increase of women athletes does not translate to the number of women sport leaders. The organizational leadership pipeline still lacks women aspirants thus, translate to a candidate pool problem for future leaders.

The participants in this study recognized the need for more women athletes to be bolder in aspiring for leadership position. The participants considered that among anybody else, athletes were the most ideal to take over leadership since they were already in the sporting system and has already acquired knowledge and background about how sport organization is being run and done. Nevertheless, based on the current situations the participants noticed that in all state sport organization there is always a lack of women aspiring for leadership positions. Subsequently, the National State Associations hence were struggling for candidates to endorse and elect.

Interviewee 5 recognized this problem to emanate from the lower level particularly at the state level. She further emphasized that the scarcity of women at the state level is the great contributing factor to the underrepresentation of women leaders in the national pool. She reiterated that because there were no women advancing from the state level of the leadership pipeline, thereby provided an opportunity for the majority (i.e. men) to dominate in the voting system at the national level: "Because if you look at how the voting system, mostly it is state representative. So it's like the national representative will have the state representative to come to the election to vote for the executive board that is representing the national. So, at the state 
INTERNATIONAL JOURNAL OF ACADEMIC RESEARCH IN BUSINESS AND SOCIAL SCIENCES

Vol. 9, No. 11, November, 2019, E-ISSN: 2222-6990 @ 2019 HRMARS

level, we already have no women representing the state then when you come to the national level, the pool is all men and then who's gonna vote [for women]."

\section{Discussion}

The experiences of the participants related to the discrepancy of gender and leadership roles account the prejudices they directly or indirectly encountered in the sport organization. Being designated in a leadership position and expected to perform under perceived gender role inhibit women to exhibit leadership capabilities and limit gender potentials (i.e., being a woman). According to Hoyt and Murphy (2016) and Vial, Napier and Brescoll (2016), the main reason for women to hardly reach top leadership position is because of the stereotype-based lack of fit between women's characteristics, skills, and aspirations and those supposed necessary for effective leadership. The researchers further explain that the gender stereotype-based expectations do not only affect who people see as "fitting" to the preconceived notion of a leader, but they also affect women themselves personally. This is apparent to what the participants voiced-out, in which they similarly said that being stereotyped can be stressful and emotionally affecting their leadership roles. At some point when the situation gets tougher, they stop for a while, reflect and intrinsically motivate themselves. Although the participants mentioned above were able to gain back their passion and zest in working towards the betterment of the sport system of the country, they were aware that sociocultural perception has already been entrenched within the sport community and can hardly be changed. Similar contemplation as suggested by Kerr and Marshall (2007) state that eradicating gender role stereotypes that continue the inequalities between men and women cannot be achieved by single individuals or in a short term. If women persistently penetrate top positions where they can influence organizational change, it is more likely that shifts in the perceptions of women at work will occur. However, the harder task to eliminate gender stereotyping involves a change in culture, both within the workplace and in the wider community (Greenhill, Auld, Cuskelly \& Hooper, 2009).

The findings of this study pertaining to the presence of gender stereotyping in the organization, such as women leaders were designated to a particular leadership positions and expected to behave according to the perceived gender role is an evident of societal perception of role congruity (Eagly \& Diekman, 2005) which suggest that women as leaders (especially in top positions) behave inconsistently with social gender role expectation (Eagly \& Karau, 2002; Ritter \& Yoder, 2004). Women are expected to behave communal characteristics, such as compassionate and mentoring (Tiell \& Dixon, 2008), which is atypical to the preconceived leadernotion as being agentic associated to allocating resources, strategic decision making, and disciplining (Tiell \& Dixon, 2008) where such characteristics are positively evaluated when it is enacted by men and perceived to be for men. In fact, Eagly and Karau (2002) described management itself as an "incongruent" social role for women because men stereotypically exhibit controlling and dominant "agentic" behaviors perceived to be more closely associated with positions of management whereas women exhibit more "communal" behaviors associated to being nurturing or serving as a role model. Therefore, women are viewed as incapable of 
handling the responsibility of power and leadership with their sensitivity traits of compassion, understanding and warmth (Turkel, 2004).

Research has identified gender stereotype as a major barrier to career development, particularly in male-dominated fields (Schein, 2007). Researchers in sport management also found that gender stereotypes created a barrier for women especially those seeking for top leadership position (Burton et al., 2009; Grappendorf et al., 2004; Whisenant et al., 2002). The consequences of gender role stereotyping may segregate men and women into leadership roles where men expected to be in the senior and executive management, while women in the secondary role or administrative staff (Burton et al., 2009; Whisenant et al., 2002), where to some extent, women assigned in these roles were cannot gain the necessary skills to advance such as in finance management, organizational decisions, and strategic planning (Hancock \& Hums, 2016; Burton et al., 2011; Grappendorf \& Lough, 2006). Evident to the premise is the comment made by Begum saying, "sometimes they are not really putting us in a right place, in the right job, where gender is the problem." Sartore and Cunningham (2007) discussed that gendered stereotypes contribute to the underrepresentation of women in top sport leadership. They explain that gender stereotypes start from, and are entrenched in, traditional practices, influencing every aspect of women's lives and enhancing the beliefs of women's inability to pursue positions of leadership.

Women leaders in this study also revealed discrimination in accessing opportunities and positions in the organization, the type of discrimination when an individual in a group is denied access to opportunities and position in organization or profession. In this current study, the evidence of male dominance in the higher position of sport organization, enables them to have the capacity to control access and promote those who exhibit the same characteristics socially and organizationally as theirs. Particularly, access discrimination happened in the election process in the organization such as women's position has no voting rights, whereas the majority of the voting rights came from the positions where men are occupying; setting specific number of women to be in the position; and promotions in positions depend to whoever is in the position making the promotion (and in most cases men are in the position). Similarly, access discrimination is manipulated by the group who are in the majority of the organization.

In this study, the occurrence of treatment and access discrimination is a manifestation of organizational prejudice attributed to homologous reproduction Kanter (1977) in the organization, which hypothetically suggest that the dominant group within an organization make every effort to "carefully guard power and privilege" by systematically reproducing like images based on social and/or physical characteristics (Sagas, Cunninghum, \& Teed, 2006). In addition, Kanter (1977) emphasized that homologous reproduction is a result of three interacting determinants in the organization's structure, which are, power, opportunity, and proportion. The male dominance of the sport organizations in this study enables them as a group to capitalize on their power to easily access organizational resources required to be successful in inhibiting opportunities for women, thereby perpetuating greater proportion in the organization. Consequently, women experience being denied access, thus fail to acquire higher positions because men typically take control of the selection process and access to positions. 
According to Dominici et al., (2009) homologous reproduction theory can explain the low recruitment of women into administrative or leadership positions in an organization. Such concept explains men who are in the positions will favor men in the recruitment process, thus exclude and discriminate against "the other" (or women in particular) who are different (Norman, 2010). Aside from the discrepancy of gender and leadership roles and organizational discrimination the participants' experienced perpetuating to the low representation of women in top leadership position of sport organization, they also encountered problems within the leadership pipeline. According to Carli and Eagly (2001), the lack of women in powerful positions used to be explained by many as a pipeline problem that is the interpretation that women with appropriate education and background were not available. The participants emphasized that the scarcity of potential women in the pipeline of leadership consequently created a candidate pool problem. It has been emphasized in the previous chapters of this study the increased participation of women in sport as athletes, but such increase does not translate to the number of women in the leadership position.

The findings of this study revealed that candidate pool problem emanates from lack of programs aiding potential women to enhance their leadership skills and to keep them engage in the system. Additionally, women also have low self-efficacy in persistently asserting their leadership capabilities and ability to approach goals, tasks and challenges signifying their lack of belief in their own capabilities to organize and manage possible situations particularly in sport management. These two contributing factors signify the lack of preparation for women to enter the leadership positions, thus signaled the scarcity of women in the leadership pool, which eventually created a pipeline problem as such that there are no available women down the pipeline to be selected for the position.

The standpoint of pipeline problem theory (Turkel, 2004) assumes the underrepresentation of women in top leadership positions is due to the lack of women with enough potential to become leaders (Mariani, 2008). It is also attributed to the inherited tendencies for women to show less of the qualities and inspirations that are important to accomplish and make progress in top level positions (Browne, 1999). In the context of sport leadership, a non-traditional career for women, the path to higher level of leadership includes coaching and lower administrative level, but since there is a shortage of women at the lower level, the path to move into the higher levels of administration become increasingly troublesome (Massengale, 2009). The increased participation of women as athletes in the country provide the potential candidates in the selection pool and could have ceased the pipeline problem, but the underrepresentation is still prevalent in the higher level of management of the sport organization. The findings of this study concurred to the "leaky pipeline" phenomenon, whereby women athletes who enter the pipeline as the potential candidates for selection subsequently leave the career field due to such reasons as personal limitations, feelings of isolation, and lack of support (Hancock \& Hums, 2016).

The outcome of pipeline issue in sport is the absence of women acting as mentors to other women and to create a social network among other women. Social networking and mentoring create a forum for the exchange of knowledge and experiences among women in sport leadership 
roles (Ismail \& Rasdi, 2007). Through social networking and mentoring, women role models in sports administration lend a voice to women in sport, show women in decision-making positions, and realistically portray the possibility that women are qualified to be sport leaders and possess the ability of leading (Coakley, 2001). In addition, pipeline problem provided men the belief that there have not been visible women long enough in the organizational pipeline wanting to advance in leadership (Turkel, 2004), thus having the opportunity to take advantage of reproducing only themselves (i.e., other male leaders).

\section{Conclusion}

The experiences of the participants related to the discrepancy of gender and leadership roles, organizational discrimination and pipeline problem accounts the difficulties women faced in moving around the sport system of the country. Gender stereotyping was evident where women were labelled as unfit for leadership capabilities and expected to exhibit perceived societal gender roles. As such, positions in the organizations were identified to be occupied by specific gender (favorably by men), and social expectation toward gender roles placed women in subordinate roles in the organizations. Access and treatment discrimination were also apparent in the sport organizations of the country. The participants directly or indirectly experience denial in opportunities and privileges, treated unjustly and verbally harassed.

The discriminatory experiences which the participants encountered do not only affect them but as well as women in sport in general, including women's involvement leading to top positions such as coaching, officiating and other subordinate administrative positions. In addition, participants also encounter difficulties relating to women's shortcomings and dispassionate attitude toward sport leadership which translate to the shortage of finding potential leaders. Furthermore, the dominance of men in sport and leadership inhibits women to penetrate access in all forms of pursuits, thereby contributed adversities in development and representation. Sport management particularly leadership in higher level of representation is still evidently occupied and govern by men. Although there have been amendments in policies and reforms have been implemented in local and international platforms but it does not still cease the issues. The more persistent women leaders navigate in the pipeline of leadership in sport the more obstacles they need to deal with which subsequently create prejudice among women in sport in general. The findings in this study concluded the prejudices within the sporting system of the country contribute to the diminishing number of women role models because they opt to get out from the system than to embroil themselves into the situation. Consequently, there is a higher possibility for a fewer aspiring women leaders to pursue for leadership position.

\section{Corresponding Author}

Aminuddin Yusof (PhD), Department of Sports Studies, Faculty of Educational Studies, University Putra Malaysia, 43400 UPM Serdang, Selangor Darul Ehsan, Malaysia.

Email: amin@upm.edu.my 
INTERNATIONAL JOURNAL OF ACADEMIC RESEARCH IN BUSINESS AND SOCIAL SCIENCES

Vol. 9, No. 11, November, 2019, E-ISSN: 2222-6990 @ 2019 HRMARS

\section{References}

Aman, M., Yusof, A., Ismail, M., \& Razali, M. A. B. (2018). Pipeline problem: Factors influencing the underrepresentation of women in the top leadership positions of sport organisations. Malaysian Journal of Movement, Health \& Exercise, 7(2), 151-166.

Browne, K. (1999). Divided labours: An evolutionary view of women at work. New Haven, CT: Yale University Press.

Burton, L. J. (2015). Underrepresentation of women in sport leadership: A review of research. Sport Management Review, 18(2), 155-165.

Carli, L. L., \& Eagly, A. H. (2001). Gender, hierarchy, and leadership: An introduction. Journal of Social Issues, 57(4), 629-636.

Charmaz, K. (2006). Constructing grounded theory: A practical guide through qualitative analysis. Thousand Oaks, CA: Sage.

Coakley, J. (2001). Sport in society: Issues and controversies (7th Ed.). Boston: McGraw-Hill.

Creswell, J. W. (2013). Qualitative inquiry \& research design: Choosing among the five approaches. Thousand Oaks, CA: Sage.

Dominici, F., Fried, L. P., \& Zeger, S. L. (2009). So few women leaders. Academe, 95(4), 25-27.

Eagly, A. H., \& Dickman, A. B. (2005). What is the problem? Prejudice as an attitude-in context. In J.F. Dovidio, P. Glick, \& L.A. Rudman (Eds.), On the nature of prejudice: Fifty years after Allport, 19-35. Maiden, MA: Blackwell

Eagly, A. C., \& Karau, S. J. (2002). Role congruity theory of prejudice toward female leaders. Psychological Review, 3, 573-598.

Ferguson, T. W. (2017). Female leadership and role congruity within the clergy: Communal leaders experience no gender differences yet agentic women continue to suffer backlash. Sex Roles, 78(2).

Greenhaus, J. H., Parasuraman, S., \& Wormley, W. M. (1990). Effects of race on organizational experiences, job performance, evaluations, and career outcomes. Academy of Management Journal, 35(1), 64-86.

Greenhill, J., Auld, C., Cuskelly, G., \& Hooper, S. (2009). The impact of organisational factors on career pathways for female coaches. Sport Management Review, 12, 229-240.

Hancock, M. G., \& Hums, M.A. (2015). A "leaky pipeline"? Factors affecting the career development of senior-level female administrators in NCAA Division I athletic departments. Sport Management Review, 19, 198-210.

Hederson, A. C., Grappendorf, H., \& Burton, L. (2011). Attributions for success and failure in athletic administration positions. Journal of Issues in Intercollegiate Athletics, 4, 257-270.

House, R. J., Hanges, P. J., Javidan, M., Dorfman, P. W., Gupta, V. (2004). Culture, Leadership, and Organization: The GLOBE studies of 62 countries. Thousand Oaks, CA: Sage.

Hoyt, C. L., \& Murphy, S. E. (2016). Managing to clear the air: Stereotype threat, women, and leadership. The Leadership Quarterly, 27, 387-399.

Inglis, S., Danylchuk, K. E., \& Pastore, D. (2000). Multiple realities of women's work experiences in coaching and athletic management. Women in Sport and Physical Activity Journal, 9, 126. 
INTERNATIONAL JOURNAL OF ACADEMIC RESEARCH IN BUSINESS AND SOCIAL SCIENCES

Vol. 9, No. 11, November, 2019, E-ISSN: 2222-6990 @ 2019 HRMARS

Ismail, M., \& Rasdi, M. R. (2007), Impact of networking on career development: Experience of high-flying women academics. Human Resource Development International, 10(2), 157172.

Kanter, R. M. (1977). Men and women of the corporation. New York: Basic Books.

Kerr, G., \& Marshall, D. (2007). Shifting the culture: Implications for female coaches. Canadian Journal for Women in Coaching, 7(4).

Knoppers, A. (1987). Gender and the coaching profession. Quest, 39(1), 9-22.

Latu, I. M., Mast, M. S., Lammers, J., \& Bombari, D. (2013). Successful female leaders empower women's behavior in leadership tasks. Journal of Experimental Social Psychology, 49, 444448.

Lovelin, M., \& Hanold, M. (2014). Female sport leaders' perceptions of leadership and management: Skills and attitude for success. Global Sport Business Journal, 2(1), 14-29.

Mariani, M. D. (2008). "A Gendered Pipeline? The Advancement of State Legislators to Congress in Five States." Politics and Gender, 4(2), 285-308.

Massengale, D. (2009). The Underrepresentation of women in interscholastic sport leadership: A qualitative study on the effects of role incongruity (Doctoral Dissertation). UNLV theses/Dissertations/Professional Papers/Capstones. Paper 64.

Daud, M. A. K., Radzi, W., Abdullah, R., \& Johari, F. (2013). The participation of women managers in managing sport: challenges and reality. Life Science, 10(3), 870-878.

Norman, L. (2010). Feeling second best: Elite women coaches' experiences. Sociology of Sport Journal, 27(1), 89-104.

Osi, E. C., Ilac, E. J., \& Amante, H. U. (2012). Satu Malaysia: Foucauldian discourse analyses on the leadership of three Malaysian women managers. Research Gate. Conference Paper presented on November 2012.

Parry, K. W. (2011). Constant Comparison. The SAGE Encyclopedia of Social Science Research Methods. Thousand Oaks, CA: Sage

Ritter, B. A., \& Yoder, J. D. (2004). Gender differences in leader emergence persist even for dominant women: An updated confirmation of role congruity theory. Psychology of Women Quarterly, 28(3), 187-193.

Saadin, I., Ramli, K., Johari, H., \& Harin, N. A. (2016). Women and barriers for upward career advancement: A survey at the Perak state secretariat, Ipoh, Perak. Procedia Economics and Finance, 35, 574-581.

Sagas, M., Cunningham, G. B., \& Teed, K. (2006). Examining homologous reproduction in the representation of assistant coaches of women's teams. Sex Roles, 55, 503-510.

Sartore, M. L., \& Cunningham, G. B. (2007). Explaining the under-representation of women in leadership positions of sports organizations: A symbolic interactionist perspective. Quest, 59(2), 244-265.

Saybani, H., Yusof, A., Soon, C. C., Hassan, A., \& Zardoshtian, S. (2015). Athletes' satisfaction as mediator of transformational leadership behaviors of coaches and football players' sport commitment relationship. World Applied Sciences Journal, 21(10), 1475-1483.

Schein, V. E. (2007). Women in management: Reflections and projections. Women in 
Management Review, 22(1), 6-18.

Scott, K., \& Brown, D. (2006). Female first, leader second? Gender bias in the encoding of leadership behavior. Organizational Behavior and Human Decision Processes, 101, 230242.

Sobritchea, C. I. (2000). Women and leadership in Asia: Towards transformative politics. Review of Women's Studies, Women and Work, X(1,2). Quezon City, Philippines: University of the Philippines.

Subramaniam, I. D., \& Arumugam, T. (2013). Barriers to women managers' career progressions in Malaysia government link companies. Australian Journal of Basic Applied Sciences, 7(22), 248-256.

Tiell, B., \& Dixon, M. A. (2008). Roles and Tasks of the senior woman administrator (SWA) in intercollegiate athletics. Journal for the Study of Sports and Athletes in Education, 2(3), 339-361.

Turkel, A. R. (2004). The hand that rocks the cradle rocks the boat: The empowerment of women. Journal of the American Academy of Psychoanalysis, 32(1), 41-54.

Whisenant, W. A., Pedersen, P. M., \& Obenour, B. L. (2002). Success and gender: Determining the rate of advancement for intercollegiate athletic directors-Brief report. Sex Roles: A Journal of Research, 5.

Vial, A. C., Napier, J. L., \& Brescoll, V. L. (2016). A bed of thorns: Female leaders and the selfreinforcing cycle of illegitimacy. The Leadership Quarterly, 27(3), 400-414.

Nachiappan, S., Osman, Z., Hassan, N. M., Jamil, N., Hussein, H., Othman, M., \& Suffian, S. (2018). An Analysis of the Criteria and Effectiveness of Using Teaching Aids in Preschool Science and Technology Components in Malaysia. International Journal of Academic Research in Progressive Education and Development, 7(1), 63-82.

Bhilawa, L., Kautsar, A. (2018). The Determinants of Relationship Between Budgetary Participation and Budgetary Slack, International Journal of Academic Research in Accounting, Finance and Management Sciences 8 (2): 155-163. 